\title{
Crown architecture, crown leaf area distribution, and individual tree growth efficiency vary across site, genetic entry, and planting density
}

\author{
Timothy J. Albaugh ${ }^{1}$ (1) Chris A. Maier ${ }^{2}$. Otávio C. Campoe ${ }^{3} \cdot$ Marco A. Yáñez $^{4}$ Eric D. Carbaugh ${ }^{1}$. David R. Carter ${ }^{1}$. \\ Rachel L. Cook ${ }^{5} \cdot$ Rafael A. Rubilar $^{6} \cdot$ Thomas R. Fox $^{7}$
}

Received: 26 March 2019 / Accepted: 10 August 2019 / Published online: 27 August 2019

○) Springer-Verlag GmbH Germany, part of Springer Nature 2019

\begin{abstract}
We examined crown architecture and within crown leaf area distribution effects on Pinus taeda L. growth in North Carolina (NC), Virginia (VA), and Brazil (BR) to better understand why P. taeda can grow much better in Brazil than in the southeastern United States. The NC, VA, and BR sites were planted in 2009, 2009, and 2011, respectively. At all sites, we planted the same two genetic entries at 618,1236, and 1854 trees $\mathrm{ha}^{-1}$. In 2013, when trees were still open grown, the VA and NC sites had greater branch diameter (24\%), branch number (14\%), live crown length (44\%), foliage mass (82\%), and branch mass (91\%), than the BR site. However, in 2017, after crown closure and when there was no significant difference in tree size, site did not significantly affect these crown variables. In 2013, site significantly affected absolute leaf area distribution, likely due to differences in live crown length and leaf area, such that there was more foliage at a given level in the crown at the VA and NC sites than at the BR site. In 2017, site was still a significant factor explaining leaf area distribution, although at this point, with crown closure and similar sized trees, there was more foliage at the BR site at a given level in the crown compared to the VA and NC sites. In 2013 and 2017, when including site, genetic entry, stand density, and leaf area distribution parameters as independent variables, site significantly affected individual tree growth efficiency, indicating that something other than leaf area distribution was influencing the site effect. Better BR P. taeda growth is likely due to a combination of factors, including leaf area distribution, crown architecture, and other factors that have been identified as influencing the site effect (heat sum), indicating that future work should include a modeling analysis to examine all known contributing factors.
\end{abstract}

Keywords Crown architecture · Growth efficiency $\cdot$ Stand density $\cdot$ Genetic entry

\section{Introduction}

Management of Pinus taeda L. in the southeastern United States (US) has steadily improved over time from extensive management of naturally regenerated or direct seeded stands with no inputs in the 1940s to intensive management today that typically includes planting of genetically improved materials on prepared sites with regular applications of competing vegetation control and fertilization (Fox et al. 2007). Over time, these improvements have resulted in large increases in productivity. However, P. taeda growth in parts of South America and Hawaii where it would be considered

Communicated by van der Maaten.

Timothy J. Albaugh

Tim_Albaugh@vt.edu

Extended author information available on the last page of the article an exotic species outside its native range can be substantially greater than that in the southeastern US (Albaugh et al. 2018; Harms et al. 2000; Samuelson et al. 2010; Wallinger 2002). For example, at 5 years of age, volume increment at a site in Brazil $\left(40 \mathrm{~m}^{3} \mathrm{ha}^{-1} \mathrm{year}^{-1}\right)$ was more than twice that of sites in the southeastern US (average of $15 \mathrm{~m}^{3} \mathrm{ha}^{-1}$ year $^{-1}$ ) (Albaugh et al. 2018). A number of hypotheses have been proposed to explain these differences in growth, including growing season length, sunlight intensity, soil characteristics, lack/presence of pathogens, sun angle, genetic entry, stand structure, and crown architecture (Harms et al. 1994; Wallinger 2002). Tested hypotheses include physiological assessments (net photosynthesis, dark respiration, stomatal conductance, and quantum yield) (Samuelson et al. 2010; Yáñez et al. 2017), foliage longevity (Albaugh et al. 2010), and light use efficiency (volume growth per unit of absorbed photosynthetically active radiation) and heat sum (volume growth per unit of heat sum or degree hours) (Albaugh et al. 
2018). Leaf level physiological assessments (measured in Hawaii and Georgia) and foliage longevity assessments (measured in Argentina and North Carolina) were comparable across sites. Site did not influence light use efficiency, but there was a significant site effect in the heat sum analysis, such that there was greater growth per unit of degree hours for P. taeda in Brazil than in North Carolina, indicating that something other than heat sum explained the growth differences.

Other species are planted outside their native range, and work has been completed in identifying areas where a given species may thrive outside its native range and in understanding why a species may do well outside its native range. Eucalyptus species native to Australia are widely planted in Brazil. Goncalves et al. (2013) used the Köppen system for climate classification to identify species that might do well when planted in Brazil, because the climatic characteristics of a specific area in Brazil matched the climatic characteristics of the species native range in Australia. Douglas-fir [Pseudotsuga menziesii (Mirb.) Franco] is native to North America but can grow better in some areas outside its native range, similar to $P$. taeda. Waring et al. (2008) found that Douglas-fir in New Zealand grew better than it did in Oregon in the native range, because there was better moisture availability in New Zealand during the growing season. Gundale et al. (2013) determined that changes in the interactions with soil biota played a role in the better growth observed when Pinus contorta Douglas ex Loudon was planted in Sweden and outside its native range in Canada. Clearly, there is a wide range of possible explanations for why a species grown outside its native range may grow better than it does in its native range.

Light interception drives forest growth (Cannell 1989), and consequently, growth is commonly related to leaf area (Vose and Allen 1988). Crown architecture in P. taeda may be influenced by silvicultural treatments such as fertilization, which may increase leaf area at a given crown position and increase crown length (Vose 1988). Fertilization increased $P$. taeda foliage biomass per unit branch mass and overall crown size, but did not affect the distribution of foliage within the crown (Gillespie et al. 1994). Compared with other southern pine species (P. elliottii Engelm. var. elliottii), P. taeda has more branches per tree and more biomass allocated to branch development (Xiao et al. 2003). A higher number of branches per tree and biomass during branch development apparently contributed to greater $P$. taeda productivity, because they allowed trees to develop a denser crown with higher leaf area that ultimately leads to faster growth rates. When comparing P. taeda in Hawaii and South Carolina, there was a two-tiered crown structure, with dominant trees in the top tier and sub-dominant trees in the bottom tier in both locations (Harms et al. 1994). However, in Hawaii, all trees had longer crowns, and the sub-dominant tree crowns extended below the dominant tree crowns, whereas in South Carolina, the bottom of the crown was the same height in both crown classes. Tree crowns in Hawaii were 4-7 m longer with five times as much leaf area than the South Carolina trees; however, the authors did note that all the differences could be attributed to genetic differences. Research on other species (Pseudotsuga menziesii Mirb.) demonstrated that canopy characteristics influence the relative location of leaf area in the crown (Maguire and Bennett 1996). Based on these studies, crown architecture can influence tree growth considerably.

Consequently, we were interested in examining foliage distribution within the crown of individual $P$. taeda trees grown in the southeastern US and Brazil where the genetic entries were the same in both locations. Our overall goal was to explain why growth of trees in Brazil can greatly exceed that of trees in the southeastern US. This information may allow managers of $P$. taeda to improve growth in the southeastern US. Furthermore, we were interested in examining foliage distribution and crown structure in open stands and after the stands had reached crown closure to determine whether the patterns observed in the open stands persisted in closed stands. Specifically, we examined the following hypotheses for $P$. taeda stands prior to and after canopy closure: (1) crown architecture (measured by branch diameter, branch number, live crown length, height to live crown, foliage mass, branch mass, leaf area, canopy density, and foliage:branch mass ratio) is the same in the southeastern US and Brazil; (2) leaf area distribution within the crown is the same in the southeastern US and Brazil; and (3) the relationship between individual tree volume increment and leaf area is the same in the southeastern US and Brazil and is not influenced by foliage distribution.

\section{Methods}

\section{Experimental design}

We installed an experiment with a split-plot design with three or four replications at three sites (Albaugh et al. 2018; Vickers et al. 2011). Two sites were located in the southeastern US: one in the Piedmont of Virginia (VA) at Reynolds Homestead $\left(36.64232^{\circ},-80.1546138^{\circ}\right)$ and one on the Atlantic Coastal Plain of North Carolina (NC) in Bladen Lakes State Forest $\left(34.83133^{\circ},-78.5873^{\circ}\right)$. The VA site was outside the native range of $P$. taeda but still in the southeastern US, which permits comparisons between the native range (NC site) and outside the native range (VA site) while still experiencing typical southeastern US growing conditions. The third site was located in Paraná State on land owned by Valor Florestal in Brazil (BR) $\left(-26.1904805^{\circ}\right.$, $\left.-49.49631^{\circ}\right)$. Soils at the VA, NC, and BR sites were 
well-drained, fine, kaolinitic, mesic Typic Kanhapludults; somewhat poorly drained, fine-loamy siliceous, semiactive, thermic Typic Paleaqualts; and well-drained Inceptisols and Hapludults, respectively. The average annual temperature during the study was $13.5,16.5$ and $16.8^{\circ} \mathrm{C}$, with average precipitation of 1218,1144 , and $1580 \mathrm{~mm} \mathrm{year}^{-1}$ for the VA, NC, and BR sites, respectively (Albaugh et al. 2018). The BR site rarely experiences extreme (below $0{ }^{\circ} \mathrm{C}$ and higher than $30^{\circ} \mathrm{C}$ ) temperatures, whereas the sites in the US regularly experience these extremes during the annual course of seasonal variation. The VA and NC sites were planted in 2009, and the BR site was planted in 2011. We expected trees to grow faster in Brazil and wanted trees at all sites to be about the same size at the same time shortly after crown closure. Planting the BR site after the southeastern US sites allowed this to occur. Trees were planted in block plots at three densities, 618, 1235, and 1853 stems ha ${ }^{-1}$. Six genetic entries were planted at each site; however, we only examined two [an open-pollinated family (OP) and one clonal variety (C3)], in this study. Planting the same genetic materials eliminated genetic variation as an explanation for any growth observed differences. The six genetic entries were selected to provide a range in crown ideotype (Martin et al. 2001; Yáñez et al. 2015) to examine silvicultural and planting density effects on ideotype growth. We selected the $\mathrm{OP}$ and $\mathrm{C} 3$ entries, because they represented the extremes in crown length and width among all genetic entries based on annual measurements of all trees. Containerized seedlings were used for $\mathrm{C} 3$ at all sites and for OP in BR. At the VA and NC sites, the OP genetic entry was planted as bare root seedlings. All seedlings were about the same size and were typical for the type of seedling, either containerized or bare root. The seedlings were produced in different nurseries (one in the US and one in Brazil), but the nurseries were operated by the same company and used similar production practices. Two levels of silviculture (operational and intensive) made up the whole-plot treatments. Operational silviculture closely matched current practices and intensive silviculture was designed to maintain trees free from competing vegetation and nutrient limitation. Under intensive silviculture, we applied vegetation control (mechanical and chemical) as needed to maintain the trees free to grow with minimal competing vegetation. Broadcast competing vegetation control was applied with site preparation; a banded application was applied after planting and at years 1 and 2 . After that time, additional entries controlled hardwood vegetation with additional spot spraying on an as-needed basis. We applied a balanced macro- and micro-nutrient fertilizer at planting and added additional nutrients at age 3 and 6 years. Annual foliar nutrient monitoring maintained the trees free from nutrient limitation. We did not test our hypotheses using the operational silviculture treatment, because the open-pollinated family was not planted in the operational silviculture treatment in BR.

Measurement plots were centered in a larger treatment plot. There were 81 trees ( 9 rows $\times 9$ planting spots) in all plots at the BR site and 63 trees ( 7 rows $\times 9$ planting spots) in all plots at the $\mathrm{NC}$ site. At the VA site, three replicates had 81 trees in each plot, and one replicate had 63 trees in each plot. The smaller treated plots were used because of space limitations. Each measurement plot had 25 trees $(5 \times 5)$, and plot size varied with initial density. Plots with different genetic entries and initial densities were adjacent. The VA and NC sites had $3.66 \mathrm{~m}$ between rows and 4.42, 2.21, and $1.47 \mathrm{~m}$ between trees on the row for the 618,1235 , and 1853 stems ha ${ }^{-1}$ initial density treatments, respectively. The BR site had slightly different initial tree spacing, with $2.4 \mathrm{~m}$ between rows and 6.8, 3.4, and $2.2 \mathrm{~m}$ between trees on the row for the 613,1225 , and 1893 stems ha $^{-1}$ initial density treatments, respectively. We considered these to be the same and refer to initial density treatments for all sites throughout this analysis as 618,1235 , and 1853 stems ha $^{-1}$. Landowner operations determined between-row spacing. Trees at all sites had nearly the same area per tree, but rectangularity was slightly different. Assuming the same growth rate, the BR trees would achieve canopy closure more rapidly between rows. Rectangularity does not influence survival or overall growth, but may affect crown width (larger with greater between-row distances) (Sharma et al. 2002), such that longer branches would be associated with wider spaced rows. Branch length was not an explanatory variable in our analyses; consequently, differences in between-row width likely had a minor effect on our results.

We completed destructive sampling of individual branches in 2012 and 2013 and non-destructive tree measurements in 2013 from the 1235 stem ha $^{-1}$ planting density. At those times in stand development, the trees had not fully occupied the site, and trees at all three planting densities appeared to be similar in regards to crown size and shape (Carbaugh 2015). Consequently, for the 2013 data, only site and genetic entry effects were examined. In 2017, we conducted destructive harvests on trees from the 618 and 1853 stems ha ${ }^{-1}$ planting densities, because they represented the extremes in crown length and width.

\section{Tree and branch measurements}

We followed the methods used by Albaugh et al. (2006) to complete our non-destructive and destructive branch assessments. In the dormant season in 2013 (January for VA and NC, July for BR), we measured tree diameter, tree height, branch diameter $2 \mathrm{~cm}$ from the stem insertion point, and distance from the top of the tree (DFT) on all living branches of 56 trees $(18,19$, and 19 trees from the VA, NC and BR sites, respectively). Selected trees were from the 
intensive silviculture treatment, $1235 \mathrm{stems} \mathrm{ha}^{-1}$ planting density with C3 (29 of 56 trees) and OP (27 of 56) genetic entries in three blocks at each site. In general, three trees were selected in each plot to represent the range in height and diameter of the trees in that treatment at that site. After measuring all branches on the 56 trees, we knew the range in DFT and branch diameter across site and genetic entry. We randomly selected 494 individual branches to represent this range in branch diameter and DFT for all genetic entries from trees that were in the treated plot but outside the measurement plot. We measured branch diameter $2 \mathrm{~cm}$ from the stem insertion point and DFT and then cut the branches at the stem insertion point. For each cut branch, we separated living foliage from branch wood and dried the foliage to a constant weight at $65^{\circ} \mathrm{C}$.

In the 2017 dormant season, we selected 72 trees across the range in tree height and diameter from the operational and intensive silviculture treatments, 618 and 1853 stems $\mathrm{ha}^{-1}$ planting density with $\mathrm{C} 3$ and OP genetic entries in three blocks at each site. Selected trees were in the treated plot but outside the measurement plot, had no obvious crown or stem defects, and at least seven of the eight neighboring trees were alive. We did not collect data on the crowns of the neighboring trees surrounding the selected trees. Trees were cut at the base, and branch diameter and DFT were measured on all live branches. On each tree, six undamaged branches from across the range in branch diameter and DFT were selected, the living foliage was separated from the branch wood, and both samples were dried to a constant weight at $65^{\circ} \mathrm{C}$. For each branch sampled for dry weight, a sub-sample of foliage was set aside prior to drying for specific leaf area determination. At all sites, we separated the needles in each fascicle in the sub-sample and scanned the needles on an Epson Expression 11000XL. Each scan included a standard to ensure that area calculations were correct and consistent. After scanning, needles were dried to a constant weight at $65{ }^{\circ} \mathrm{C}$. For the VA and NC sites, we used WinRHIZO (Arsenault et al. 1995), and at the BR site, we used ImageJ in the leaf area $\mathrm{R}$ package (https://cran.r-project.org/packa $\mathrm{ge}=$ LeafArea) to calculate projected area. WinRHIZO was originally intended for root area assessments; it has been adjusted for use with needles. Pierret et al. (2013) compared the performance of WinRHIZO and ImageJ and found very good correlations for length $\left(r^{2}=0.997\right)$ and diameter $\left(r^{2}=0.991\right)$, giving confidence that any differences measured were real and not a function of methodology.

We estimated projected leaf area on each branch. First, we used a mixed model to develop a relationship to estimate foliage and branch mass using all available data from the 926 destructively harvested branches (494 in 2013, and 432 in 2017, branch wood data only available in 2017). Significant independent variables were branch diameter, DFT, site, silviculture, genetic entry, and planting density for the foliage and branch relationships. Tree age and size (stem volume estimated as diameter squared times height) from where each branch originated were included in model development, but neither was a significant explanatory variable in either the foliage or branch relationships. P. taeda leaf life span is typically 2 years in the southeastern US and in South America (Albaugh et al. 2010), and this characteristic likely prevented tree age and size from influencing our relationships. Foliage does not survive long enough to achieve very different light regimes over time, and hence, branch size and DFT relationships were similar for the 2013 and 2017 measurements. We applied these relationships to branches measured in the intensive silviculture treatment in 2013 and 2017. We calculated the ratio of foliage to branch mass for each branch and then summed the foliage mass for each tree and calculated canopy density (foliage mass per live crown length) for each tree.

We developed a relationship to estimate specific leaf area using specific leaf area data collected from the six undamaged branches on each tree. Significant independent variables used to estimate specific leaf area were DFT, site, and planting density. We estimated leaf area for each branch as the product of foliage mass and specific leaf area. There were no specific leaf area data available for 2013; we used the relationship from the 2017 data adjusted to remove the site effect (averaged across site) and set the adjustment for planting density to be the same as that for the 1854 trees $\mathrm{ha}^{-1}$ planting density, because there were no trees sampled in the 1235 trees ha ${ }^{-1}$ planting density in 2017. This may have resulted in an overestimate of individual branch leaf area in 2013. The overestimation would have been applied to all branches, because the only planting density measured in 2013 was the 1254 trees ha $^{-1}$ planting density.

We examined treatment effects on individual tree foliage distribution using absolute and relative values for the relationship between leaf area and DFT. We completed absolute and relative analyses, because there were differences in crown size across sites, and differences in vertical distribution have been explained by tree and crown size (Weiskittel et al. 2009). If we did not examine the relative distribution, varying crown length and amounts of leaf area in the crown within a measurement period and between measurement years may have masked or overwhelmed differences in foliage distribution. Similarly, the relative analysis controlled for differences in tree and stand development resulting from the 2-year age difference between the southeastern US sites and the BR site. For the analysis using absolute data, beginning at the tree top, branches were grouped every 10 and $50 \mathrm{~cm}$ of DFT in 2013 and 2017, respectively, and leaf area was summed for all the branches in each group. Initially, we selected a group size of $50 \mathrm{~cm}$, which resulted in about 20 bins for the largest trees (Weiskittel et al. 2009). However, the model did not converge well on the smaller 2013 trees, 
and consequently, we selected the $10-\mathrm{cm}$ grouping to ensure model convergence. Grouping the branches in this way assumes a horizontal branch insertion angle (90 degrees). The absolute analysis used the summed leaf area and the midpoint of each group's respective DFT. For the relative analysis, the maximum DFT was identified for each tree, and relative DFT for each branch on that tree was calculated as follows:

$\mathrm{DFT}_{\mathrm{r}}=\mathrm{DFT} / \mathrm{DFT}_{\mathrm{m}} \times 100$,

where $\mathrm{DFT}_{\mathrm{r}}$ is relative DFT, and $\mathrm{DFT}_{\mathrm{m}}$ is the maximum DFT for the tree. Beginning at the tree top, branches were grouped every 10 relative DFT units in 2013 and 2017, and leaf area was summed for all the branches in each group. Relative leaf area was determined by summing the leaf area for each relative DFT group, identifying the maximum leaf area from the relative DFT groups on each tree and calculating relative leaf area for each relative DFT group as follows:

$\mathrm{LA}_{\mathrm{r}}=\mathrm{LA} / \mathrm{LA}_{\mathrm{m}} \times 100$,

where $\mathrm{LA}_{\mathrm{r}}$ is the relative leaf area for that relative DFT, LA is the absolute leaf area for that relative DFT, and $\mathrm{LA}_{m}$ is the maximum leaf area for any relative DFT group on the tree. We used $\mathrm{LA}_{\mathrm{m}}$ to relativize the leaf area data, because it corresponds to the asymptote in the model we used to describe leaf area distribution within the crown (see below) and sets the maximum value possible on this axis. If, for example, we had used the total amount of leaf area on the tree as the denominator in Eq. 2, our relative values would never equal the asymptote in the model.

For each tree measured in 2013 and 2017 and for relative and absolute data, we fit a beta model (Archontoulis and Miguez 2015; Yin et al. 2003):

$Y=\beta 0\left(1+((\beta 1-t) /(\beta 1-\beta 2))(t / \beta 1)^{\beta 1 /(\beta 1-\beta 2)}\right.$,

where $Y$ is leaf area (absolute or relative), $\beta 0$ is the maximum value of leaf area (absolute or relative), $\beta 1$ is the DFT when $Y=\beta 0$, $\mathrm{t}$ is DFT, and $\beta 2$ is the inflection point at which the rate of change in leaf area is at its maximum. We used PROC NLIN with the Gauss optimization method to estimate $\beta 0, \beta 1$, and $\beta 2$ for each tree (SAS-Institute 2002).

For each measurement year, we examined tree volume increment as a function of total tree leaf area and treatment [site, genetic entry, and planting density (only for 2017)] and tree volume increment as a function of total leaf area, treatment, and the beta model parameters $(\beta 0, \beta 1$, and $\beta 2)$. Individual tree volume increment $\left(\mathrm{m}^{3}\right.$ tree $^{-1}$ year $\left.^{-1}\right)$ was calculated as the product of diameter squared and height divided by the number of years of growth that had occurred to that point in time. There were no interim measurements for the harvested trees, because they were removed from the area outside the measurement plot; consequently, we were only able to estimate the mean annual increment for these trees. For 2013 measurements, the VA and NC sites were 4 years old and the BR site was 2 years old. For 2017 measurements, the VA and NC sites were 8 years old and the BR site was 6 years old. We used PROC GLIMMIX to identify significant effects in each model. The full model for the tree volume increment versus leaf area and treatment included total leaf area, site, genetic entry, and planting density (only in 2017) and all interactions. The full model for the tree volume increment versus leaf area, treatment, and beta model parameters included total leaf area, site, genetic entry, and planting density (only in 2017), $\beta 0, \beta 1$, and $\beta 2$ and their interactions. In both models, terms were removed from the model until all remaining terms were significant at the $p=0.05$ level. Residuals were examined, and no bias was found.

\section{Statistical analyses}

We used PROC GLIMMIX to test for site and treatment effects on tree diameter, height, height to live crown, length of live crown, foliage biomass, branch biomass, leaf area, canopy density, foliage:branch mass ratio, the absolute and relative beta model parameters, branch diameter, and number of branches per tree (SAS-Institute 2002). In the relative beta model parameters analysis, we included tree size (stem volume estimated as diameter squared times height) as a covariate. In these analyses, site, planting density, genetic entry, and their interactions were fixed effects. Random effects were block and genetic entry by block (Schabenberger 2013). Site was a fixed effect, because we selected sites in specific areas (in the southeastern US and Brazil) (Littell et al. 2006; Piepho et al. 2003). We used the Tukey-Kramer adjustment to determine means separation. We completed the analyses by year (2013 and 2017). For 2013, only one planting density was measured (1236 tree $\mathrm{ha}^{-1}$ ), so determination of planting density effects was not possible.

All statistical tests were evaluated with alpha equal to 0.05. Residuals were examined for bias for all statistical tests; none were found.

\section{Results}

In 2013, site significantly affected tree diameter, height, length of live crown, foliage biomass, branch biomass, leaf area, canopy density, foliage:branch mass ratio, branch diameter, and number of branches per tree, whereas genetic entry was not significant for any of the variables measured (Table 1). The site-by-genetic entry interaction significantly affected foliage mass, foliage area and canopy density. Taller trees with longer live crowns containing more foliage mass and leaf area were found at the VA site compared to NC 
Table 1 Statistical summary ( $p$ values) for branch and tree metrics from the open grown trees measured in 2013 and after crown closure in 2017 for crown characteristics at sites in Virginia, North Carolina,

\begin{tabular}{|c|c|c|c|c|c|c|c|c|c|c|c|c|}
\hline \multirow[t]{3}{*}{ Year } & \multirow[t]{3}{*}{ Effect } & \multicolumn{2}{|l|}{ Branch } & \multicolumn{9}{|l|}{ Tree } \\
\hline & & & & \multirow[t]{2}{*}{ Diameter } & \multirow[t]{2}{*}{ Height } & \multirow{2}{*}{$\begin{array}{l}\text { Live } \\
\text { crown } \\
\text { length }\end{array}$} & \multirow{2}{*}{$\begin{array}{l}\text { Height to } \\
\text { Live crown }\end{array}$} & \multirow{2}{*}{$\begin{array}{l}\text { Foliage } \\
\text { Mass }\end{array}$} & \multirow{2}{*}{$\begin{array}{l}\text { Leaf } \\
\text { Area }\end{array}$} & \multirow{2}{*}{$\begin{array}{l}\text { Branch } \\
\text { Mass }\end{array}$} & \multirow{2}{*}{$\begin{array}{l}\text { Canopy } \\
\text { Density }\end{array}$} & \multirow{2}{*}{$\begin{array}{l}\text { Foliage:branch } \\
\text { Mass ratio }\end{array}$} \\
\hline & & Diameter & Number & & & & & & & & & \\
\hline 2013 & Site $(\mathrm{S})$ & 0.001 & 0.001 & 0.000 & 0.000 & 0.000 & 0.926 & 0.000 & 0.000 & 0.000 & 0.005 & 0.000 \\
\hline 2013 & Genetic entry (G) & 0.289 & 0.108 & 0.602 & 0.295 & 0.346 & 0.837 & 0.359 & 0.377 & 0.844 & 0.137 & 0.068 \\
\hline 2013 & $\mathrm{~S} * \mathrm{G}$ & 0.060 & 0.228 & 0.093 & 0.324 & 0.382 & 0.826 & 0.026 & $\mathbf{0 . 0 3 0}$ & 0.297 & 0.008 & 0.361 \\
\hline 2017 & $\mathrm{~S}$ & 0.116 & 0.239 & 0.240 & 0.064 & 0.224 & 0.001 & 0.133 & 0.040 & 0.681 & 0.006 & 0.725 \\
\hline 2017 & G & 0.599 & 0.378 & 0.926 & 0.577 & 0.469 & 0.662 & 0.630 & 0.672 & 0.550 & 0.599 & 0.218 \\
\hline 2017 & $\mathrm{~S}^{*} \mathrm{G}$ & 0.764 & 0.587 & 0.735 & 0.278 & 0.227 & 0.089 & 0.591 & 0.630 & 0.933 & 0.119 & 0.501 \\
\hline 2017 & Density (D) & 0.002 & 0.042 & 0.028 & 0.280 & 0.029 & 0.000 & 0.005 & 0.007 & 0.001 & 0.005 & 0.003 \\
\hline 2017 & $\mathrm{~S} * \mathrm{D}$ & 0.837 & 0.023 & 0.526 & 0.673 & 0.108 & 0.006 & 0.830 & 0.814 & 0.795 & 0.253 & 0.283 \\
\hline 2017 & $\mathrm{G}^{*} \mathrm{D}$ & 0.584 & 0.442 & 0.880 & 0.779 & 0.901 & 0.271 & 0.744 & 0.685 & 0.708 & 0.658 & 0.249 \\
\hline 2017 & $\mathrm{~S} * \mathrm{G}^{*} \mathrm{D}$ & 0.459 & 0.947 & 0.994 & 0.982 & 0.977 & 0.536 & 0.442 & 0.438 & 0.500 & 0.227 & 0.605 \\
\hline
\end{tabular}

In 2013, only trees in the 1236 tree ha $^{-1}$ plots were measured, and in 2017, only trees in the 618 and 1854 trees ha ${ }^{-1}$ plots were measured. Values in bold are $<0.05$

and BR sites and at the NC site compared to the BR site (Table 2). There were more branches per tree at the VA site ( 51 branches tree $^{-1}$ ) than at the other sites (NC and BR sites both had 40 branches tree $^{-1}$ ) (Table 2). The site ranking for branch diameter, tree diameter, and branch mass was $\mathrm{VA}=\mathrm{NC}>\mathrm{BR}$ (Table 2).

In 2017, site significantly affected height to live crown and canopy density (Table 1). Planting density significantly affected tree diameter, length of live crown, foliage biomass, branch biomass, leaf area, canopy density, foliage:branch mass ratio, and branch diameter. A significant site by planting density effect was observed for number of branches and the height to live crown. Genetic entry did not affect any of the variables measured. The height to live crown was lower at the NC site than at the other sites (Table 2). Although the BR site was planted 2 years after the sites in VA and $\mathrm{NC}$, trees at all sites were the same size (tree diameter and height) with the same live crown length, foliage and branch mass, foliage:branch mass ratio, average branch diameter, and number of branches per tree (Table 2). Low-density (618 trees $\mathrm{ha}^{-1}$ ) trees had larger diameter branches, larger tree diameter, a longer live crown, a lower height to live crown, more foliage mass, greater leaf area, more branch mass, greater canopy density, and a lower foliage:branch mass ratio than high density (1854 trees ha $\left.{ }^{-1}\right)$ trees. The site-by-planting density interaction for height to live crown was such that the magnitude of the increase in height to live crown observed between planting density levels at each site differed. The site-by-planting density interaction for number of branches resulted from the VA and NC sites having the same number of branches with low and high planting density, but at the BR site, there was a large difference between and Brazil where two genetic entries (a clone and an open-pollinated family) of Pinus taeda were planted at 618, 1236, and 1854 trees ha ${ }^{-1}$ 


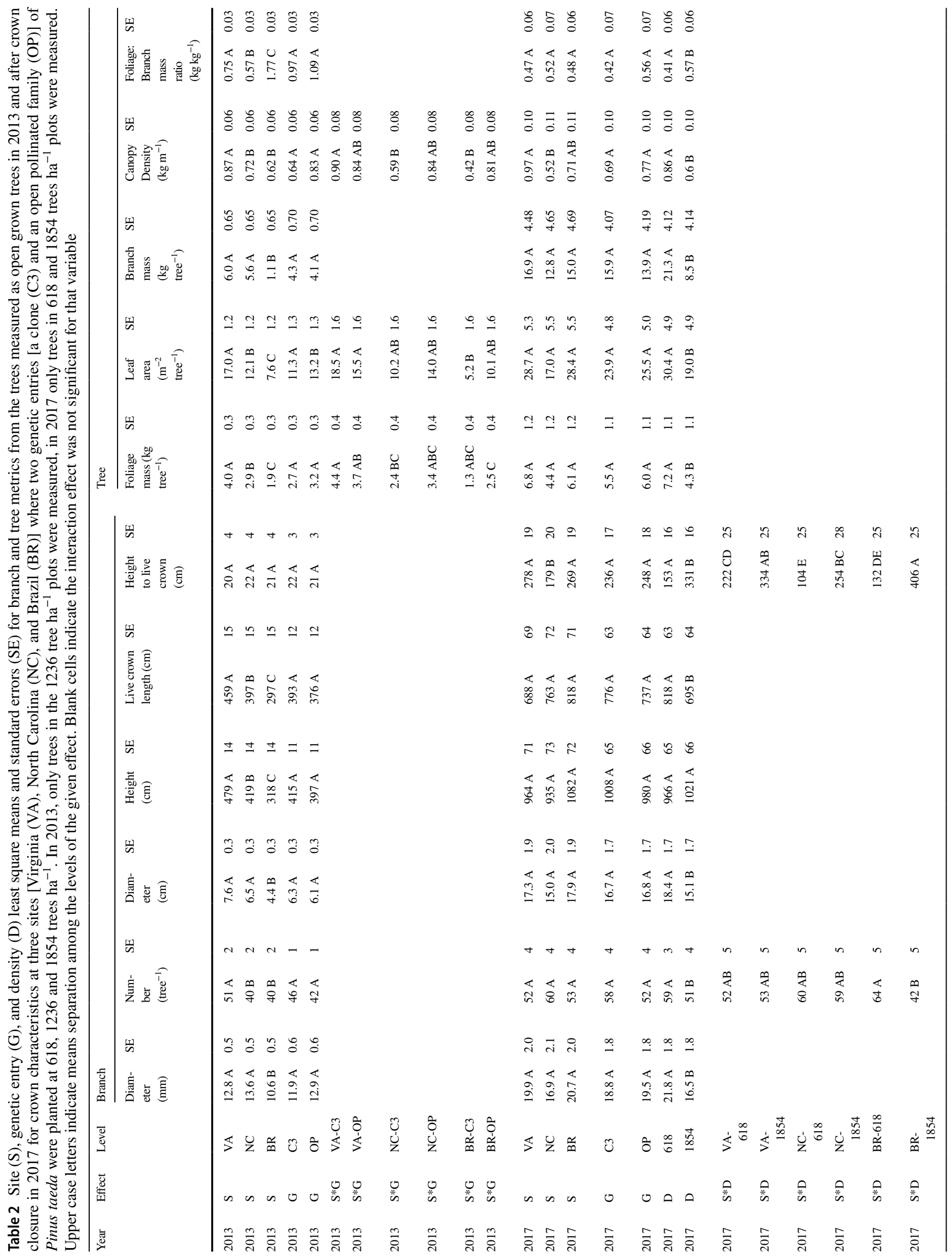




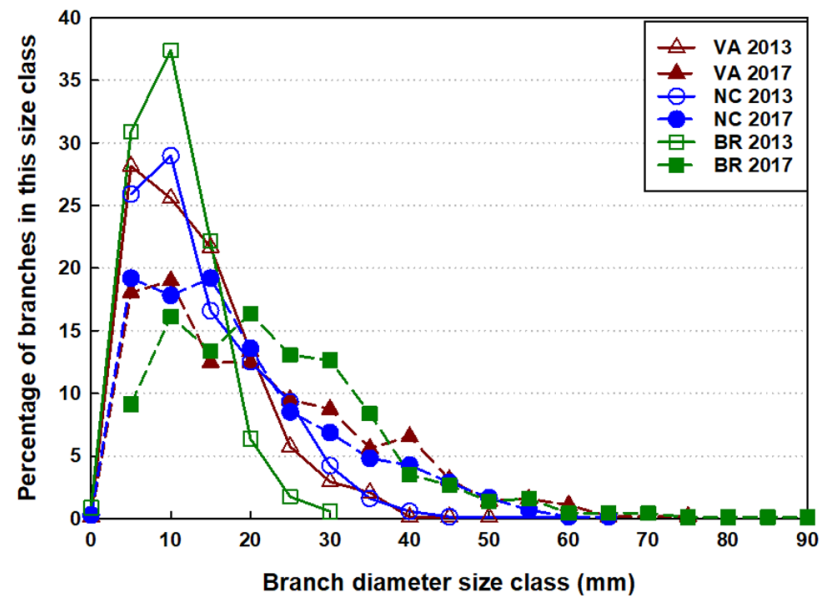

Fig. 1 Branch diameter size-class distribution for trees measured in 2013 and 2017 for sites in Virginia (VA), North Carolina (NC) and Brazil (BR) where the same two Pinus taeda genetic entries were planted at three densities

significant explanatory variables when included in the volume increment leaf area analysis (Table 5). For the 2013 and 2017 relationships, the influence of the site effect varied across years. For example, in 2013, the parameter estimate for site for VA and NC had a greater positive effect on the intercept (0.003404 and 0.001701 , respectively) compared to $\mathrm{BR}(0)$. When interacting with the $\beta 1$ parameter (DFT where leaf area equals maximum leaf area), the site effect had a negative estimate for VA and $\mathrm{NC}(-0.00011$ and -0.00003 , respectively) and a neutral estimate for BR (0) (Table 5). The positive effect on the intercept would increase growth per unit leaf area, and a negative effect on $\beta 1$ would push the point of maximum leaf area further down in the crown.

There was no clear pattern for the DFT and foliage:branch mass relationship in 2013 (Fig. 7a). However, in 2017, there was a similar pattern across sites, where the foliage:branch ratio decreased as the DFT increased (Fig. 7b).

\section{Discussion}

\section{Crown architecture}

The BR trees grew faster than the VA and NC trees, in agreement with other data reported from this study (Albaugh et al. 2018). Consequently, stands in the two regions were developing at different rates. The experiment was designed with different planting years (2009 for VA and NC sites and 2011 for the BR site), so that even though stands in the US and BR were growing at different rates, they would be at the same stand developmental stage and would reach crown closure in the same calendar year. There were significant site differences in most crown architecture variables in 2013 between the US sites and BR, which leads us to reject our first hypothesis for open grown stands. However, in 2017, after crown closure and when the trees were the same size, site did not significantly affect most crown architecture variables, which leads us to accept our first hypothesis for closed canopy stands. It was surprising to find crown architecture variables similar across sites given these different growth rates. However, stand developmental stage and the amount of inter-tree competition rather than age are likely more influential for these crown variables (Albaugh et al. 2006). Similarly, Weiskettel et al. (2009) found that large amounts of variation in the total and vertical distribution of leaf area were accounted for by crown size.

Under both an open canopy and after crown closure, genetic entry generally did not have an influence on crown architecture metrics. This result was also surprising given that $\mathrm{C} 3$ and $\mathrm{OP}$ were chosen, because, of the six genetic
Fig. 2 Distance from the top of the tree and branch diameter for all the branches measured in 2013 (a) and 2017 (b) for sites in Virginia (VA), North Carolina (NC), and Brazil (BR) where the same two Pinus taeda genetic entries were planted at three densities. Each point represents one branch

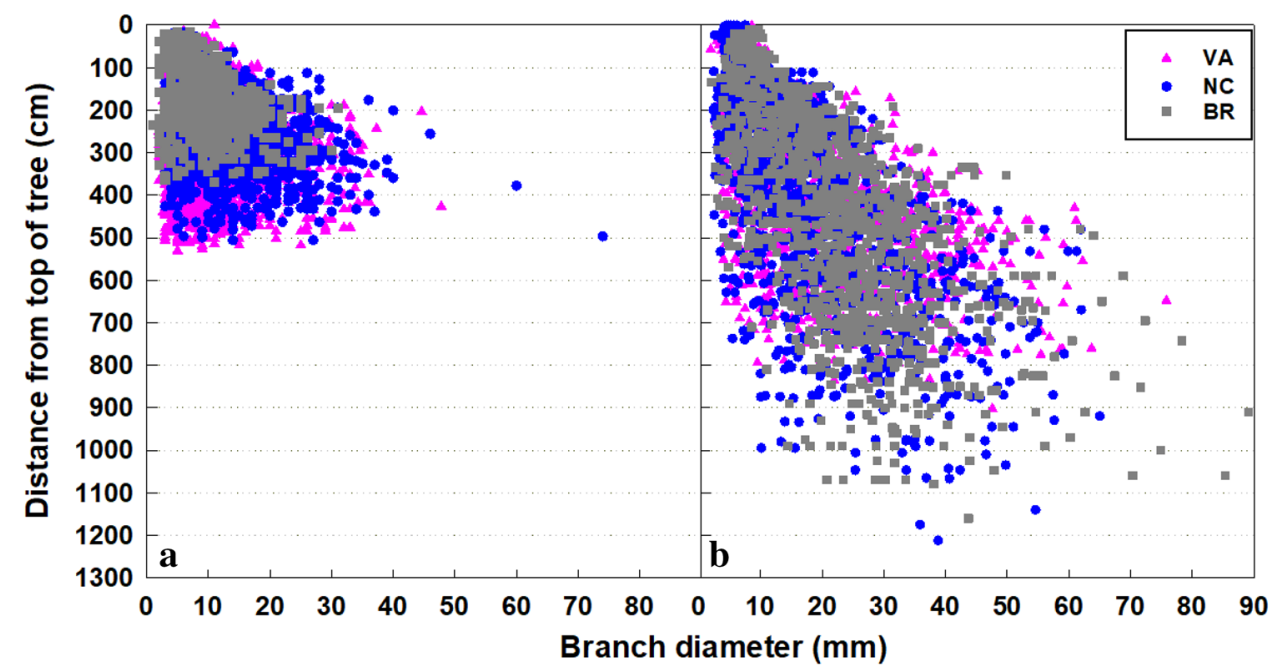




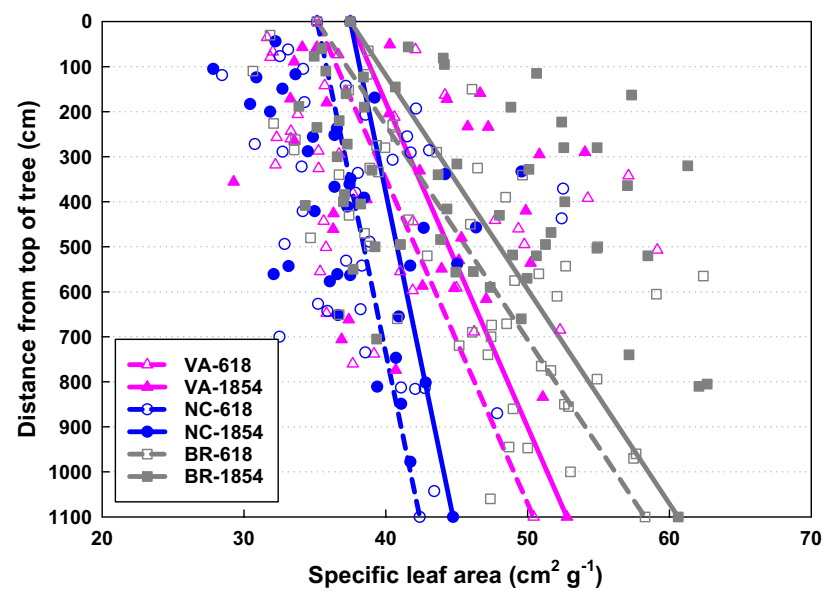

Fig. 3 Distance from the top of the tree (DFT) and specific leaf area for all the branches where foliage was collected and specific leaf area measured in 2017 for the sites in Virginia (VA), North Carolina (NC), and Brazil (BR) where the same two Pinus taeda genetic entries were planted at three densities. Trees were selected from two planting densities (618 and 1854 trees $\mathrm{ha}^{-1}$ ). Significant independent variables explaining specific leaf area were DFT, site, and planting density. Regression lines are shown for each site and planting density combination

entries at the stand scale, they represented the extreme crown sizes, where $\mathrm{C} 3$ had the smallest crown diameter and live crown length and OP had the largest. At the same time, planting density significantly influenced all crown architecture metrics after crown closure. As noted previously, the low planting density treatment $\left(618\right.$ trees $\left.^{-1}\right)$ had more and larger branches, a longer live crown length, a lower height to live crown, more foliage and branch mass, more leaf area, a greater canopy density and a lower foliage:branch mass ratio compared to the high density treatment (1854 trees ha ${ }^{-1}$ ). These results were likely due to the greater available space for individual tree growth prior to the onset of intra-specific competition resulting from crown closure and are similar to those found in the literature for sites where thinning reduced this competitive effect (Yu et al. 2003). Lower density, from planting or thinning, permits light to reach branches lower in the crown, reducing self-pruning and facilitating a positive carbon balance, resulting in longer live crown lengths, lower height to live crown and ultimately greater leaf area (Peterson et al. 1997; Sprugel 2002; Sprugel et al. 1991).

Our crown measurements were similar to those found in the literature. Branch diameter distribution shifted with stand development, where maximum branch diameter was approximately $40 \mathrm{~mm}$ in 2013 before crown closure and about twice that size in 2017 after canopy closure and was similar to other reports in the literature (Figs. 1,2) (Albaugh et al. 2006). Our range in live crown length $(\sim 3-8 \mathrm{~m})$, number of branches $\left(\sim 40-60\right.$ branches tree $\left.^{-1}\right)$, branch mass $\left(\sim 1-20 \mathrm{~kg} \mathrm{tree}^{-1}\right)$, foliage mass $\left(\sim 1-7 \mathrm{~kg}^{-1} \mathrm{ree}^{-1}\right)$, leaf area $\left(\sim 5-100 \mathrm{~m}^{2}\right.$ tree $\left.^{-1}\right)$, and specific leaf area $\left(\sim 30-60 \mathrm{~cm}^{2} \mathrm{~g}^{-1}\right)$ were similar to corresponding measurements from Harms et al. (1994): $2.5-10 \mathrm{~m}, 23-79$ branches tree ${ }^{-1}, 2-105 \mathrm{~kg}$ branch tree ${ }^{-1}, 1-40 \mathrm{~kg}$ foliage tree ${ }^{-1}, 0.4-168 \mathrm{~m}^{2}$ tree $^{-1}$, and $17-54 \mathrm{~cm}^{2} \mathrm{~g}^{-1}$, respectively. However, in Harms et al. (1994), measurements were from 25-year-old trees rather than the 2-8-year-old trees in this study, again emphasizing
Table 3 Statistical summary ( $p$ values) for the non-linear model parameters estimated for the beta model (a sigmoid function) used to describe foliage distribution at absolute and relative scales within the crown. $\beta 0, \beta 1$, and $\beta 2$ are the asymptote of foliage in the crown, the point in the crown where the asymptote is achieved and the inflection point at which the increase in leaf area in the crown is maximized, respectively

\begin{tabular}{|c|c|c|c|c|c|c|c|}
\hline \multirow[t]{2}{*}{ Year } & \multirow[t]{2}{*}{ Effect } & \multicolumn{3}{|c|}{ Absolute scale } & \multicolumn{3}{|c|}{ Relative scale } \\
\hline & & $\beta 0$ & $\beta 1$ & $\beta 2$ & $\beta 0$ & $\beta 1$ & $\beta 2$ \\
\hline 2013 & Site $(\mathrm{S})$ & 0.000 & 0.000 & 0.029 & 0.592 & 0.347 & 0.411 \\
\hline 2013 & Genotype (G) & 0.014 & 0.537 & 0.656 & 0.783 & 0.017 & 0.635 \\
\hline 2013 & $\mathrm{~S}^{*} \mathrm{G}$ & 0.024 & 0.153 & 0.653 & 0.877 & 0.211 & 0.246 \\
\hline 2013 & Volume (V) & & & & 0.478 & 0.824 & 0.239 \\
\hline 2017 & $\mathrm{~S}$ & 0.001 & 0.158 & 0.043 & 0.349 & 0.000 & $\mathbf{0 . 0 0 0}$ \\
\hline 2017 & Genotype (G) & 0.847 & 0.751 & 0.708 & 0.850 & 0.877 & 0.123 \\
\hline 2017 & $\mathrm{~S} * \mathrm{G}$ & 0.065 & 0.830 & 0.367 & 0.281 & 0.112 & 0.003 \\
\hline 2017 & Density (D) & 0.009 & 0.170 & 0.159 & 0.562 & 0.394 & 0.980 \\
\hline 2017 & $S * D$ & 0.606 & 0.840 & 0.961 & 0.607 & 0.028 & 0.040 \\
\hline 2017 & $\mathrm{G}^{*} \mathrm{D}$ & 0.338 & 0.691 & 0.745 & 0.351 & 0.851 & 0.974 \\
\hline 2017 & $\mathrm{~S} * \mathrm{G}^{*} \mathrm{D}$ & 0.492 & 0.482 & 0.476 & 0.605 & 0.488 & 0.131 \\
\hline 2017 & $\mathrm{~V}$ & & & & 0.888 & 0.694 & 0.059 \\
\hline
\end{tabular}

Trees used in the analysis were measured in 2013 and 2017 for crown characteristics at three sites (Virginia, North Carolina, and Brazil) where two genotypes (a clone and an open-pollinated family) of Pinus taeda were planted at 618,1236 , and 1854 tree ha ${ }^{-1}$. In 2013, only trees in the 1236 tree ha ${ }^{-1}$ plots were measured, and in 2017, only trees in the 618 and 1854 trees ha ${ }^{-1}$ plots were measured. Values in bold are $<0.05$. Relative scale data are adjusted for distance from the top of the tree, maximum leaf area at a given level and tree size based on stem volume (V) (diameter squared times height) 


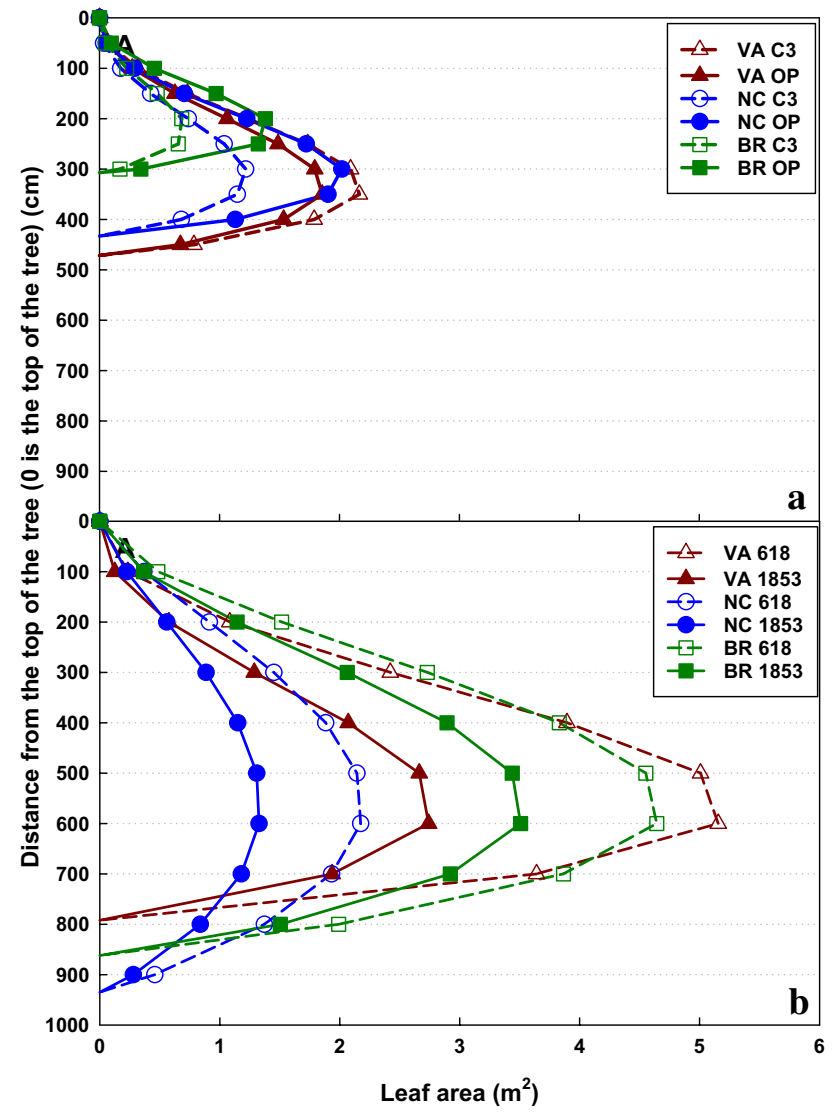

Fig. 4 Absolute leaf area distribution for trees in 2013 (a) and 2017 (b) from sites in Virginia (VA), North Carolina (NC), and Brazil (BR) where the same two Pinus taeda genetic entries [a clone (C3) and an open-pollinated family (OP)] were planted at three densities. In 2013, measured trees were from the 1236 tree ha $^{-1}$ planting density, whereas in 2017 , trees were measured in the 618 and 1854 trees ha ${ }^{-1}$ planting densities. Site and genetic entry effects were significant in 2013; site and planting density effects were significant in 2017

the importance of stand development rather than age for crown metrics. The range in the foliage:branch mass ratio prior to crown closure in 2013 (0.5-1.8, Table 2) was similar to that reported by Xiao et al. (2003) for 3- and 4-year-old trees, which were still in a largely open grown condition. In 2017, after crown closure, average foliage:branch mass ratios were lower $(0.4-0.6)$ than those for the open grown trees.

\section{Leaf area distribution}

There was a significant site effect on absolute leaf area distribution, in open grown trees in 2013 and after canopy closure in 2017, and consequently, we rejected our second hypothesis that leaf area distribution is the same in the southeastern US and Brazil (Fig. 4). For the open grown trees, it is likely that the significant effects were due largely to differences in live crown length and leaf area, in agreement

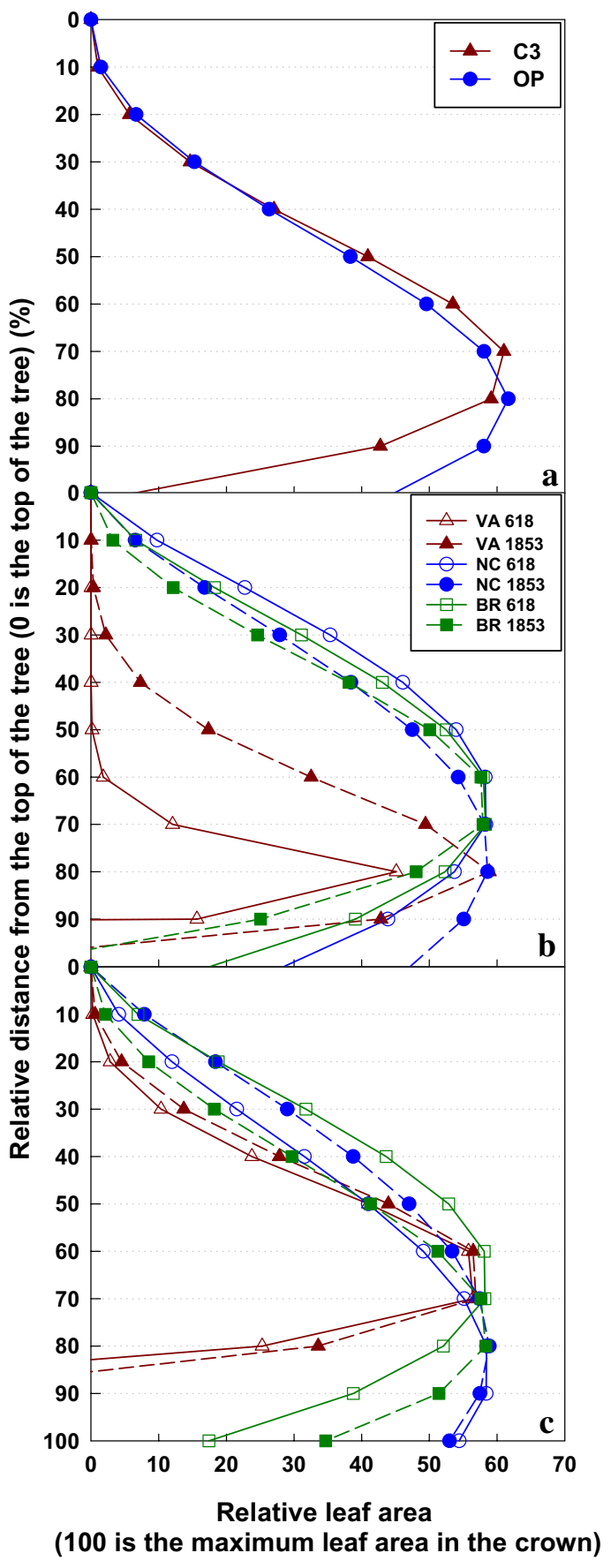

Fig. 5 Relativized leaf area distribution for trees in 2013 (a) when the only significant effect was genetic entry [a clone (C3) or openpollinated (OP)] and in 2017 when genetic entry [C3 (b) and OP (c), site (Virginia (VA), North Carolina (NC) and Brazil (BR))] and planting density ( 618 and 1854 trees $\mathrm{ha}^{-1}$ ) were significant factors explaining the relative amount and crown position of leaf area. Tree scale data were relativized by setting the maximum distance to the top of the tree and leaf area to 100 with all other measurements for that tree scaled to the maximum. Tree stem volume (diameter squared times height) was included as a covariate to further adjust for tree size. These methods removed the effect of tree size and leaf area amounts to focus on how leaf area was positioned in the crown of similar sized trees 


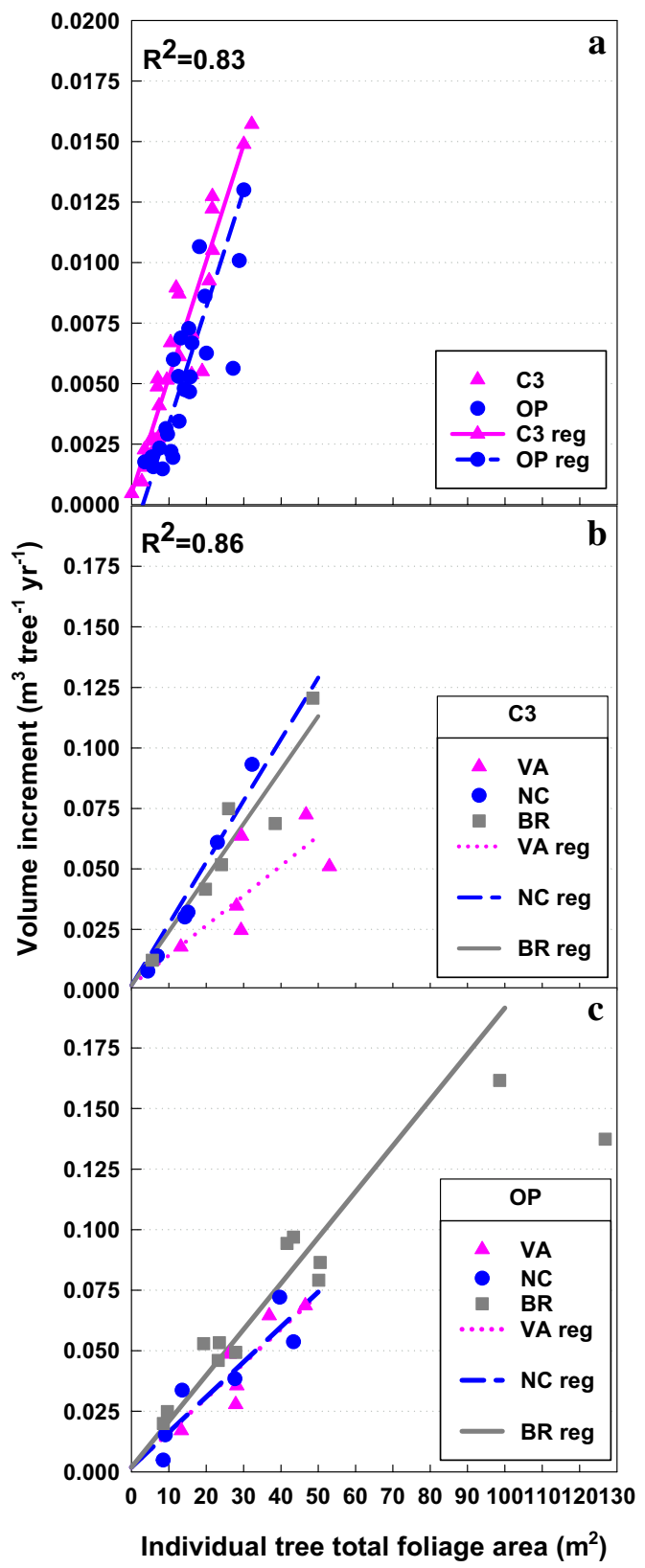

Fig. 6 Individual tree stem volume increment versus corresponding tree total leaf area for 2013 (a), where genetic entry [a clone (C3) or open-pollinated (OP)] significantly affected the relationship and for 2017 where genetic entry (C3, b, and OP, c) and site [Virginia (VA), North Carolina (NC) and Brazil (BR)] significantly affected the relationship. Regression (reg) lines show significant effects

with Weiskittel et al. (2009). There was a significant planting density effect after crown closure, where low planting density trees had more leaf area at a given crown location than did high planting density trees. It was not possible to test for a planting density effect in the open grown trees, because we only measured one planting density. Interestingly, relative leaf area distribution in open grown trees did not have a significant site effect, but did exhibit a genetic

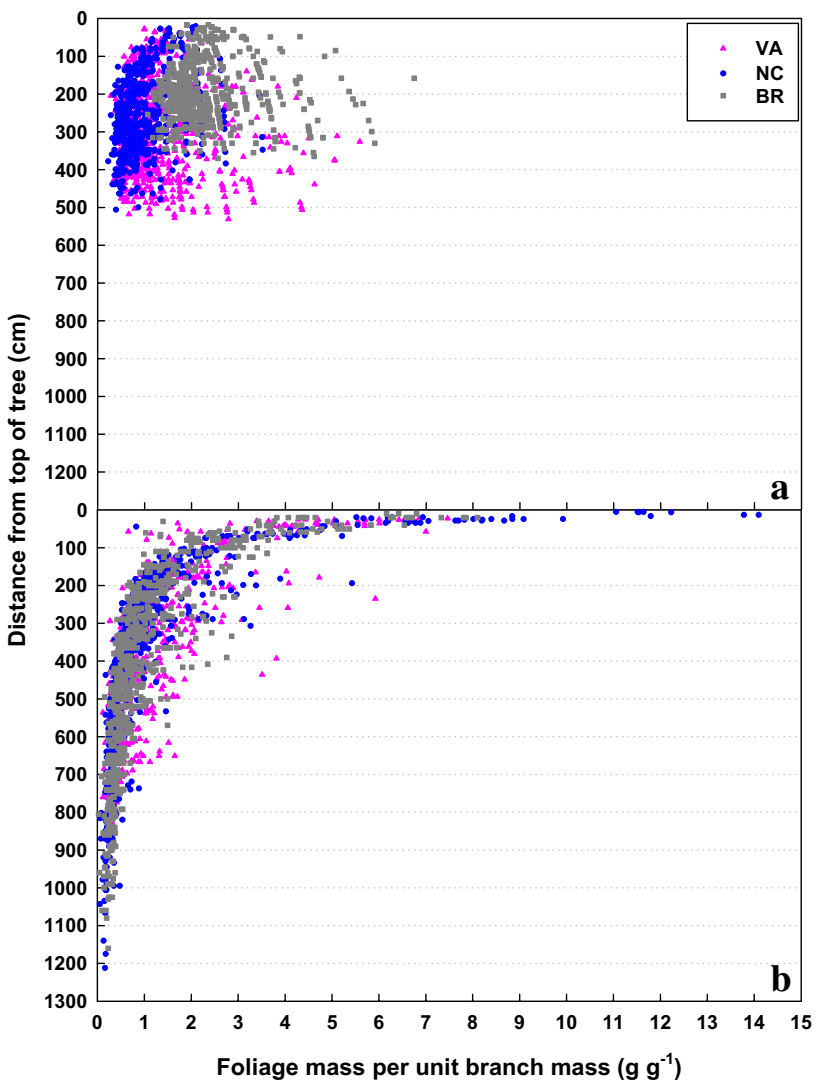

Fig. 7 Distance from the top of the tree and foliage mass per unit branch mass for trees measured in 2013 (a) and 2017 (b) for sites in Virginia (VA), North Carolina (NC), and Brazil (BR) where the same two Pinus taeda genetic entries were planted at three densities. In 2017 , there were 11 branches from the NC site where the foliage mass per unit branch mass exceeded 15 (the maximum $x$ axis value shown) and ranged up to 90 . All of these branches were less than $12 \mathrm{~cm}$ from the top of the tree and are not shown for clarity of presentation

entry effect, where the point in the crown with the largest amount of leaf area was shifted upward in $\mathrm{C} 3$ relative to $\mathrm{OP}$ (Fig. 5a). We selected genetic entries for a range of crown ideotype (Martin et al. 2001) with C3 representing a crop ideotype (tall, narrow crown) and OP a competition ideotype (short, wide crown). Open grown trees retained their ideotype characteristics, which would position more leaf area closer to the top of the tree in $\mathrm{C} 3$ relative to OP. After crown closure, in 2017, these early ideotype differences appeared to be masked (Albaugh et al. 2016). Chmura et al. (2009) found similar results, where genetic effects were relatively small compared to environmental (silvicultural level and stand density) effects after crown closure.

Our concern that differences in tree size might mask significant effects appears to have been warranted (Weiskittel et al. 2009). If we had only observed the open grown trees, we would have accepted the second hypothesis for the relative data and rejected it for the absolute data. Apparently, 
Table 4 Site (S), genotype (G), and density (D) least square means for the non-linear model parameters estimated for the beta model (a sigmoid function) used to describe foliage distribution at absolute and relative scales within the crown. $\beta 0, \beta 1$, and $\beta 2$ are the asymptote of foliage in the crown, the point in the crown where the asymptote is achieved and the inflection point at which the increase in leaf area in the crown is maximized, respectively

\begin{tabular}{|c|c|c|c|c|c|c|c|c|}
\hline \multirow[t]{2}{*}{ Year } & \multirow[t]{2}{*}{ Effect } & \multirow[t]{2}{*}{ Level } & \multicolumn{3}{|c|}{ Absolute scale } & \multicolumn{3}{|c|}{ Relative scale } \\
\hline & & & $\beta 0$ & $\beta 1$ & $\beta 2$ & $\beta 0$ & $\beta 1$ & $\beta 2$ \\
\hline 2013 & $\mathrm{~S}$ & VA & $2.0 \mathrm{~A}$ & $335 \mathrm{~A}$ & $196 \mathrm{~A}$ & $65 \mathrm{~A}$ & $77 \mathrm{~A}$ & $47 \mathrm{~A}$ \\
\hline 2013 & $\mathrm{~S}$ & $\mathrm{NC}$ & $1.6 \mathrm{~A}$ & $315 \mathrm{~A}$ & $193 \mathrm{AB}$ & $62 \mathrm{~A}$ & $80 \mathrm{~A}$ & $50 \mathrm{~A}$ \\
\hline 2013 & $\mathrm{~S}$ & $\mathrm{BR}$ & $1.0 \mathrm{~B}$ & $222 \mathrm{~B}$ & $134 \mathrm{~B}$ & $58 \mathrm{~A}$ & $74 \mathrm{~A}$ & $41 \mathrm{~A}$ \\
\hline 2013 & G & C3 & $1.3 \mathrm{~A}$ & $284 \mathrm{~A}$ & $170 \mathrm{~A}$ & $61 \mathrm{~A}$ & $74 \mathrm{~A}$ & $45 \mathrm{~A}$ \\
\hline 2013 & G & OP & $1.8 \mathrm{~B}$ & $293 \mathrm{~A}$ & $179 \mathrm{~A}$ & $62 \mathrm{~A}$ & $81 \mathrm{~A}$ & $47 \mathrm{~A}$ \\
\hline 2017 & $\mathrm{~S}$ & VA & $3.9 \mathrm{~A}$ & $584 \mathrm{~A}$ & $332 \mathrm{~A}$ & $65 \mathrm{~A}$ & $83 \mathrm{~A}$ & $59 \mathrm{~A}$ \\
\hline 2017 & $S$ & $\mathrm{NC}$ & $1.7 \mathrm{~B}$ & $507 \mathrm{~A}$ & $188 \mathrm{~B}$ & $53 \mathrm{~A}$ & $66 \mathrm{~B}$ & $24 \mathrm{~B}$ \\
\hline 2017 & S & $\mathrm{BR}$ & $4.1 \mathrm{~A}$ & $598 \mathrm{~A}$ & $259 \mathrm{AB}$ & $59 \mathrm{~A}$ & $71 \mathrm{~B}$ & $31 \mathrm{~B}$ \\
\hline 2017 & $\mathrm{G}$ & $\mathrm{C} 3$ & $3.1 \mathrm{~A}$ & $569 \mathrm{~A}$ & $270 \mathrm{~A}$ & $59 \mathrm{~A}$ & $73 \mathrm{~A}$ & $41 \mathrm{~A}$ \\
\hline 2017 & G & OP & $3.2 \mathrm{~A}$ & $556 \mathrm{~A}$ & 249 A & $58 \mathrm{~A}$ & $73 \mathrm{~A}$ & $35 \mathrm{~A}$ \\
\hline 2017 & $\mathrm{D}$ & 618 & $3.9 \mathrm{~A}$ & $593 \mathrm{~A}$ & $289 \mathrm{~A}$ & $61 \mathrm{~A}$ & $72 \mathrm{~A}$ & $38 \mathrm{~A}$ \\
\hline 2017 & $\mathrm{D}$ & 1854 & $2.5 \mathrm{~B}$ & $533 \mathrm{~A}$ & $230 \mathrm{~A}$ & $57 \mathrm{~A}$ & $74 \mathrm{~A}$ & $38 \mathrm{~A}$ \\
\hline 2017 & $S * G$ & VA-C3 & & & & & & $71 \mathrm{~A}$ \\
\hline 2017 & $\mathrm{~S} * \mathrm{G}$ & VA-OP & & & & & & $46 \mathrm{~B}$ \\
\hline 2017 & $\mathrm{~S}^{*} \mathrm{G}$ & NC-C3 & & & & & & $21 \mathrm{C}$ \\
\hline 2017 & $\mathrm{~S}^{*} \mathrm{G}$ & NC-OP & & & & & & $27 \mathrm{BC}$ \\
\hline 2017 & $S * G$ & BR-C3 & & & & & & $30 \mathrm{BC}$ \\
\hline 2017 & $S * G$ & BR-OP & & & & & & $33 \mathrm{BC}$ \\
\hline 2017 & $S * D$ & VA-618 & & & & & $85 \mathrm{~A}$ & $63 \mathrm{~A}$ \\
\hline 2017 & $\mathrm{~S} * \mathrm{D}$ & VA-1854 & & & & & $80 \mathrm{~A}$ & $54 \mathrm{AB}$ \\
\hline 2017 & $S^{*} \mathrm{D}$ & NC-618 & & & & & $66 \mathrm{~B}$ & $26 \mathrm{C}$ \\
\hline 2017 & $S * D$ & NC-1854 & & & & & $65 \mathrm{~B}$ & $23 \mathrm{C}$ \\
\hline 2017 & $\mathrm{~S} * \mathrm{D}$ & BR-618 & & & & & $65 \mathrm{~B}$ & $25 \mathrm{C}$ \\
\hline 2017 & $S * D$ & BR-1854 & & & & & $76 \mathrm{AB}$ & $37 \mathrm{BC}$ \\
\hline
\end{tabular}

Trees used in this analysis were measured in 2013 and 2017 for crown characteristics at three sites (Virginia, North Carolina, and Brazil) where two genotypes (a clone and an open-pollinated family) of Pinus taeda were planted at 618,1236 , and 1854 tree ha $^{-1}$. In 2013, only trees in the 1236 tree ha ${ }^{-1}$ plots were measured, and in 2017, only trees in the 618 and 1854 trees $^{-1} \mathrm{a}^{-1}$ plots were measured. Relative scale data are adjusted for distance from the top of the tree, maximum leaf area at a given level in the crown, and tree size based on stem volume (diameter squared times height) stand developmental processes (e.g., moving from open grown to crown closure) have a large effect on how crown architecture influences growth, and the treatments imposed in this study (genetic entry and planting density) can overwhelm site effects. Given that absolute foliage distribution changes with stand development, it may be problematic to use it to explain differences in growth among the sites.

After canopy closure, in the relative foliage distribution analysis, maximum leaf area at the BR site was achieved higher in the crown in the 618 trees ha ${ }^{-1}$ compared to the 1854 trees $\mathrm{ha}^{-1}$, whereas at the VA and NC sites, there were no differences detected in the crown location of maximum leaf area (Fig. 5b, c; Tables 3, 4). Leaf area shifting towards the top of the tree has been attributed to less dominant trees (Xu and Harrington 1998), species differences (Weiskittel et al. 2009), low intensity silviculture (no fertilization or weed control) (Xiao et al. 2003), and less dominant trees and trees in low-density stands (Maguire and Bennett 1996). Our results for BR appear to agree with Maguire and Bennett
(1996). That the trees in VA and NC did not demonstrate an upward shift of relative foliage distribution with lower density does not appear to be related to the other factors identified in the literature. Across sites, dominance should have been relatively similar given our criteria for tree selection. Similarly, our treatments controlled for genetics, and we examined the same silviculture and planting density levels. At this point, it is unclear why relative leaf area distribution in the crown was influenced by density at one site and not the others.

After canopy closure, specific leaf area increased with increasing DFT (Fig. 3), similar to data from the literature (Maguire and Bennett 1996; Maier et al. 2002; Weiskittel et al. 2008). The site ranking for the specific leaf area DFT relationship was $\mathrm{BR}>\mathrm{VA}>\mathrm{NC}$. These data suggest a site effect on foliar anatomy, i.e., the ratio of mechanical-tophotosynthetic foliage tissue is altered, where needles with a high DFT (located far from the top of the tree) at the BR site had lower needle density. Wang et al. (2019) found that 


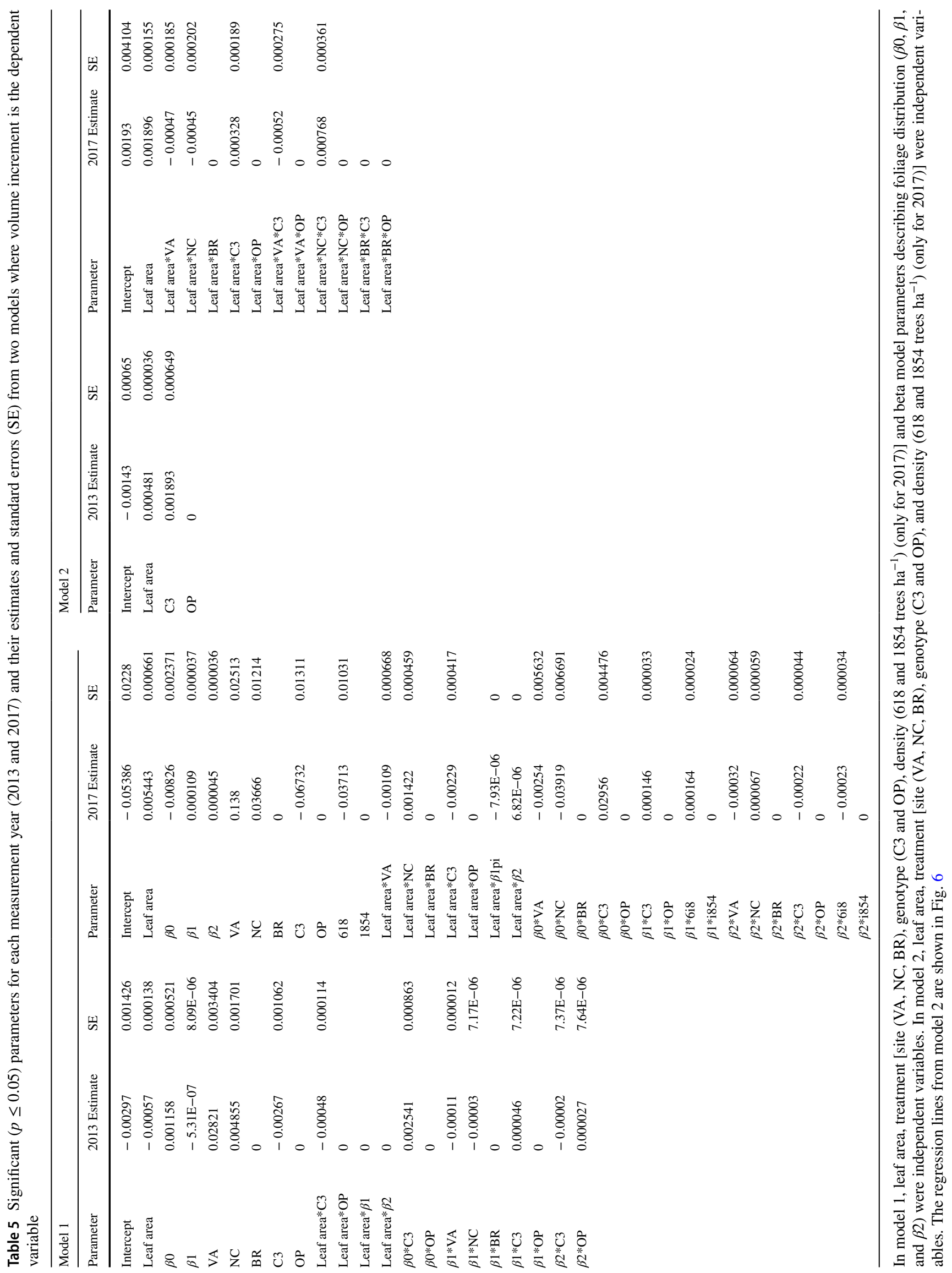


as needle length increased, needle density decreased and the proportion of mechanical-to-photosynthetic tissue increased, and this was correlated with greater needle hydraulic conductance and photosynthesis. We did not measure needle length in this study; however, Albaugh et al. (2010) found needles in Argentina between 22 and 236\% (3-12 cm depending on flush) longer than those in North Carolina in a study comparing growth differences similar to those observed here between the VA and NC sites and the BR site. Evidence suggests that there are no differences in lower canopy photosynthesis across sites (Wang et al. 201x; Yáñez et al. 2017). However, we hypothesize that lower canopy needles at the BR site have greater water use efficiency and are able to maintain greater stomatal conductance and photosynthesis at high vapor pressure deficit levels that would contribute to the greater growth observed at the BR site. We anticipate completing additional destructive harvests in the future and plan to measure these anatomical and physiological differences at that time.

\section{Individual tree growth efficiency}

When only including treatment effects (site, genetic entry, and planting density) as independent variables, only genetic entry significantly affected the volume increment versus leaf area relationship in open grown trees in 2013. This changed with canopy closure in 2017, when site and genetic entry influenced the volume increment-leaf area relationship, with the NC and BR sites having greater individual tree growth efficiency for the $\mathrm{C} 3$ and $\mathrm{OP}$ genetic entries, respectively (Fig. 6). When including treatment effects and leaf area distribution parameters as independent variables, site was a significant factor in open grown and closed crown trees (Table 5). Consequently, we rejected our third hypothesis that the relationship between individual tree volume increment and leaf area is the same in the southeastern US and Brazil and is not influenced by foliage distribution. That the leaf area distribution parameters were significant in the volume growth-leaf area relationship underscores the importance of assessing not only the amount but also the distribution of foliage as well whether trees are open grown or crown closure has been achieved.

Xiao et al. (2003) suggested that relatively low foliage:branch mass ratios, observed here after crown closure, facilitated crown development and a higher leaf area carrying capacity in P. taeda. P. taeda is a morphologically plastic species, having the ability to produce and maintain large dense crowns when provided the appropriate resources [e.g., (Clark and Saucier 1991; Harms et al. 1994)]. This plasticity may partially explain the differences we observe as site effects. Greater leaf area throughout the crown at the BR site is indicative of increased productivity, and the increase in volume growth per unit leaf area (increased growth efficiency) observed across sites is similar to fertilizer effects, which also show increased growth efficiency at the stand scale (Albaugh et al. 1998). Given that site was still significant in predicting increased growth efficiency when crown leaf area distribution parameters and treatment (genetic entry and planting density) effects were included in the analysis indicates that something other than foliage distribution in the crown is influencing the site effect. In this analysis, the focus was volume growth; however, when examining total tree growth (including stems, branches, roots, and foliage), differences in partitioning across sites may become important. Changes in growth efficiency have previously been explained, in part by changes in partitioning in fertilized and non-fertilized stands (Albaugh et al. 1998). Perhaps, this is the next hypothesis to examine to better understand site effects on growth in this study. At the same time, heat sum was determined to play a role in the site effects in earlier work at these sites (Albaugh et al. 2018). A more detailed modeling exercise that incorporates the heat sum analysis, foliage distribution, crown architecture, and the changes we observed as stands move from open grown to crown closure is warranted. It is likely that the explanation for better growth in Brazil will be a combination of factors that by themselves only incrementally explain the increase, and an analysis that incorporates several of these hypotheses at the same time should be investigated.

Acknowledgements We appreciate support from the Forest Productivity Cooperative and members for their role in the establishment and management of the trials central to this publication. We gratefully acknowledge the support provided by the National Science Foundation Center for Advanced Forest Systems, the Department of Forest Resources and Environmental Conservation at Virginia Polytechnic Institute and State University, the Departamento de Silvicultura, Facultad de Ciencias Forestales, Universidad de Concepción, the Department of Forestry and Environmental Resources at North Carolina State University and the Departamento de Ciências Florestais Universidade Federal de Lavras. Funding for this work was provided in part by the Virginia Agricultural Experiment Station and the McIntire-Stennis Program of the National Institute of Food and Agriculture, U.S. Department of Agriculture. The use of trade names in this paper does not imply endorsement by the associated agencies of the products named or criticism of similar ones not mentioned. We are grateful for ArborGen for supplying the genetic material, for the assistance of K. Peer and C. Sawyer at The Reynolds Homestead, H.C. Rohr at the North Carolina Forest Service's Bladen Lakes State Forest, and the personnel at Valor Florestal for the installation and ongoing maintenance of the study sites.

Author contribution statement Albaugh: collected data, completed analysis, wrote and edited manuscript. Maier: collected data, provided support for work, provided comment on manuscript and analysis. Campoe: provided support for work, provided comment on manuscript and analysis. Yáñez: collected data, provided comment on manuscript and analysis. Carbaugh: collected data, provided comment on manuscript and analysis. Carter: provided support for work, provided comment on manuscript and analysis. Cook: collected data, provided support for work, provided comment on manuscript and analysis. Rubilar: provided support for work, provided comment on manuscript and analysis. 
Fox: original idea, provided support for work, provided comment on manuscript and analysis.

\section{Compliance with ethical standards}

Conflict of interest The authors declare that they have no conflict of interest.

\section{References}

Albaugh TJ, Fox TR, Yanez MA, Rubilar RA, Goldfarb B (2016) Will crown ideotype help determine optimum varietal silviculture? Proceedings of the 18th biennial southern silvicultural research conference Gen. Tech. Rep. SRS-212, pp 302-307

Albaugh TJ, Allen HL, Dougherty PM, Kress LW, King JS (1998) Leaf area and above- and belowground growth responses of loblolly pine to nutrient and water additions. For Sci 44(2):317-328

Albaugh TJ, Allen HL, Fox TR (2006) Individual tree crown and stand development in Pinus taeda under different fertilization and irrigation regimes. For Ecol Manage 234(1):10-23

Albaugh TJ, Allen HL, Stape JL, Fox TR, Rubilar RA, Carlson CA, Pezzutti R (2010) Leaf area duration in natural range and exotic Pinus taeda. Can J For Res 40:224-234

Albaugh TJ, Fox TR, Maier CA, Campoe OC, Rubilar RA, Cook RL, Raymond JE, Alvares CA, Stape JL (2018) A common garden experiment examining light use efficiency and heat sum to explain growth differences in native and exotic Pinus taeda. For Ecol Manage 425:35-44

Archontoulis SV, Miguez FE (2015) Nonlinear regression models and applications in agricultural research. Agron J 107(2):786-798

Arsenault JL, Pouleur S, Messier C, Guay R (1995) WinRHIZO, a root measuring system with a unique overlap correction method. HortScience 30:906

Cannell MGR (1989) Physiological basis of wood production: a review. Scand J For Res 4:459-490

Carbaugh ED (2015) A comparison of crown attributes for six genotypes of Pinus taeda as affected by site and management intensity. Master in Forestry, Virginia Tech

Chmura DJ, Tjoelker MG, Martin TA (2009) Environmental and genetic effects on crown shape in young loblolly pine plantations. Can J For Res 39:691-698

Clark A, Saucier JR (1991) Influence of planting density, intensive culture, geographic location, and species on juvenile wood formation in southern pine. Georgia Forest Research Paper 85, pp 1-14

Fox TR, Jokela EJ, Allen HL (2007) The development of pine plantation silviculture in the southern United States. J For 105(5):337-347

Gillespie AR, Allen HL, Vose JM (1994) Amount and vertical distribution of foliage of young loblolly pine trees as affected by canopy position and silvicultural treatment. Can J For Res 24(7):1337-1344

Goncalves JL, Alvares CA, Higa AR, Silva LD, Alfenas AC, Stahl J, Ferraz SF, Lima WP, Brancalion PH, Hubner A, Bouillet JP, Laclau JP, Nouvellon Y, Epron D (2013) Integrating genetic and silvicultural strategies to minimize abiotic and biotic constraints in Brazilian eucalypt plantations. For Ecol Manage 301:6-27

Gundale MJ, Kardol P, Nilsson MC, Nilsson U, Lucas RW, Wardle DA (2013) Interactions with soil biota shift from negative to positive when a tree species is moved outside its native range. New Phytol 202:415-421

Harms WR, De Bell DS, Whitesell CD (1994) Stand and tree characteristics and stockability in Pinus taeda plantations in Hawaii and South Carolina. Can J For Res 24:511-521
Harms WR, Whitesell CD, DeBell DS (2000) Growth and development of loblolly pine in a spacing trial planted in Hawaii. For Ecol Manage 126:13-24

Littell RC, Milliken GA, Stroup WW, Wolfinger RD, Schabenberger O (2006) SAS for mixed models. SAS Publishing, Cary

Maguire DA, Bennett WS (1996) Patterns in vertical distribution of foliage in young coastal Douglas-fir. Can J For Res 26:1991-2005

Maier CA, Johnsen KH, Butnor J, Kress LW, Anderson PH (2002) Branch growth and gas exchange in 13-year-old loblolly pine (Pinus taeda) trees in response to elevated carbon dioxide concentration and fertilization. Tree Physiol 22:1093-1106

Martin TA, Johnsen KH, White TL (2001) Ideotype development in southern pines: rationale and strategies for overcoming scalerelated obstacles. For Sci 47(1):21-28

Peterson JA, Seiler JR, Nowak J, Ginn SE, Kreh RE (1997) Growth and physiological responses of young loblolly pine stands to thinning. For Sci 43:529-534

Piepho HP, Buchse A, Emrich K (2003) A hitchhiker's guide to mixed models for randomized experiments. J Agronomy Crop Sci 189(5):310-322

Pierret A, Gonkhamdee S, Jourdan C, Maeght JL (2013) IJ_Rhizo: an open source software to measure scanned images of root samples. Plant Soil 373:531-539

Samuelson LJ, Eberhardt TL, Butnor J, Stokes TA, Johnsen KH (2010) Maximum growth potential in loblolly pine: results from a 47-year-old spacing study in Hawaii. Can J For Res 10:1914-1929

SAS-Institute (2002) SAS Version 9.1 TS. SAS Institute, Inc: Cary, NC

Schabenberger O (2013) SAS Code for some advanced experimental designs. UC Regents. http://people.math.carleton.ca/ smill s/2016-17/STAT5505/SAS\%20Code\%20for\%20Some\%20Adv anced\%20Experimental\%20Designs.htm. Accessed 13 Dec 2017

Sharma M, Burkhart HE, Amateis RL (2002) Spacing rectangularity effect on the growth of loblolly pine plantations. Can J For Res $32: 1451-1459$

Sprugel DG (2002) When branch autonomy fails: Milton's Law of resource availability and allocation. Tree Physiol 22:1119-1124

Sprugel DG, Hinckley TM, Schaap W (1991) The theory and practice of branch autonomy. Ann Rev Ecol Syst 22:309-334

Vickers LA, Fox TR, Stape JL, Albaugh TJ (2011) Silviculture of varietal loblolly pine plantations: second year impacts of spacing and silvicultural treatments on varieties with differing crown ideotypes. In: Butnor J (ed) USDA Forest Service. Southern Research Station, Asheville, pp 361-365

Vose JM (1988) Patterns of leaf-area distribution within crowns of nitrogen-fertilized and phosphorus-fertilized loblolly-pine trees. For Sci 34(3):564-573

Vose JM, Allen HL (1988) Leaf-area, stemwood growth, and nutrition relationships in loblolly-pine. For Sci 34(3):547-563

Wallinger RS (2002) Intensive forest management: Growing wood and preserving biodiversity in the U.S. South and Brazil. For Oper Rev 4(3):5-11

Wang B, Seiler JR, Fox TR, Maier CA, Peterson JA, Albaugh TJ, Carter DR. Increased shade tolerance and enhanced light harvesting of lower crown foliage contributed to high productivity of loblolly pine (Pinus taeda L.) in Brazil. Tree Physiol (in preparation)

Wang N, Palmroth S, Maier CA, Domec JC, Oren R (2019) Anatomical changes with needle length are correlated with leaf structural and physiological traits across five Pinus species. Plant, Cell Environ 2019:1-15

Waring RH, Nordmeyer A, Whitehead D, Hunt J, Newton M, Thomas C, Irvine J (2008) Why is the productivity of Douglas-fir higher in New Zealand than in its native range in the Pacific Northwest, USA? For Ecol Manage 255(2008):4040-4046

Weiskittel AR, Temesgen H, Wilson DS, Maguire DA (2008) Sources of within-and between-stand variability in specific leaf area of three ecologically distinct conifer species. Ann For Sci 65 
Weiskittel AR, Kershaw JA Jr, Hofmeyer PV, Seymour RS (2009) Species differences in total and vertical distribution of branch- and tree-level leaf area for the five primary conifer species in Maine, USA. For Ecol Manage 258:1695-1703

Xiao Y, Jokela EJ, White TL (2003) Species differences in crown structure and growth performance of juvenile loblolly and slash pine. For Ecol Manage 174(1-3):295-313

Xu MG, Harrington TB (1998) Foliage biomass distribution of loblolly pine as affected by tree dominance, crown size, and stand characteristics. Can J For Res 28(6):887-892

Yáñez MA, Fox TR, Seiler JR, Guerra F, Baettig R, Zamundio F, Gyenge JE (2017) Within-crown acclimation of leaf-level physiological and morphological parameters in young loblolly pine stands. Trees Struct Funct 31:1849-1857
Yáñez MA, Fox TR, Seiler JR (2015) Early responses of loblolly pine varieties and families to silvicultural intensity. For Ecol Manage 356:204-215

Yin X, Goudriaan J, Lantinga EA, Vos J, Spiertz JHJ (2003) A flexible sigmoid function of determinate growth. Ann Bot 91:361-371

Yu SF, Chambers JL, Tang ZM, Barnett JP (2003) Crown characteristics of juvenile loblolly pine 6 years after application of thinning and fertilization. For Ecol Manage 180(2003):345-352

Publisher's Note Springer Nature remains neutral with regard to jurisdictional claims in published maps and institutional affiliations.

\section{Affiliations}

\section{Timothy J. Albaugh ${ }^{1}$ (D) Chris A. Maier ${ }^{2}$. Otávio C. Campoe ${ }^{3} \cdot$ Marco A. Yáñez $^{4}$ - Eric D. Carbaugh ${ }^{1}$. David R. Carter ${ }^{1}$. Rachel L. Cook ${ }^{5} \cdot$ Rafael A. Rubilar $^{6} \cdot$ Thomas R. Fox $^{7}$}

\author{
Chris A. Maier \\ cmaier@fs.fed.us \\ Otávio C. Campoe \\ Marco A. Yáñez \\ marcoyanez@utalca.cl \\ Eric D. Carbaugh \\ ecarbaug@vt.edu \\ David R. Carter \\ davidcarter@vt.edu \\ Rachel L. Cook \\ rlcook@ncsu.edu \\ Rafael A. Rubilar \\ rafaelrubilar@udec.cl \\ Thomas R. Fox \\ tom.fox@rayonier.com
}

otavio.campoe@gmail.com; otavio.campoe@ufla.br
1 Department of Forest Resources and Environmental Conservation, Virginia Tech, 228 Cheatham Hall, Blacksburg, VA 24061, USA

2 USDA Forest Service, 3041 Cornwallis Road, Research Triangle Park, NC, USA

3 Departamento de Ciências Florestais, Universidade Federal de Lavras, Lavras, MG, Brazil

4 Núcleo Científico Multidisciplinario, Universidad de Talca, Avenida Lircay s/n, Talca, Chile

5 Department of Forestry and Environmental Resources, North Carolina State University, Raleigh, NC 27695-8008, USA

6 Cooperativa de Productividad Forestal, Facultad de Ciencias Forestales, Universidad de Concepción, Victoria 631, Casilla, 160-C, Concepción, Chile

7 Rayonier, Inc. Forest Research Center, Yulee, FL 32097 , USA 